\title{
Tingginya Prevalensi MRSA pada Isolat Klinik Periode 2010- 2014 di RSUD Dr. Saiful Anwar Malang, Indonesia
}

\section{The High Prevalence of MRSA in Clinical Isolates in the period of 2010-2014 in Dr. Saiful Anwar General Hospital Malang, Indonesia}

\author{
Dewi Erikawati, Dewi Santosaningsih, Sanarto Santoso \\ Laboratorium Mikrobiologi Fakultas Kedokteran Universitas Brawijaya Malang
}

\begin{abstract}
ABSTRAK
Methicillin Resistant Staphylococcus aureus (MRSA) merupakan bakteri patogen terpenting penyebab infeksi terkait perawatan di rumah sakit di dunia. Penelitian ini bertujuan untuk membandingkan prevalensi dan pola resistensi antibiotik dari isolat MRSA di RSUD Dr. Saiful Anwar Malang, Jawa Timur, Indonesia selama kurun waktu 2010-2014. Isolat MRSA didapatkan dari berbagai spesimen klinik, seperti darah, pus, sputum, dan urin. Kami mendeteksi isolat MRSA secara fenotipik, selanjutnya melakukan uji kepekaan antibiotik sesuai standar dari Clinical and Laboratory Standards Institute (CLSI) 2014. Secara keseluruhan, didapatkan 772 isolat Staphylococcus aureus, 38,2\% diantaranya merupakan isolat MRSA. Prevalensi MRSA tertinggi didapatkan pada tahun 2012 (45,3\%), sedangkan prevalensi terendah pada tahun 2013 (33,5\%). Kasus MRSA paling sering ditemukan dari pus (49\%). Ditemukan penurunan resistensi isolat MRSA dari darah terhadap chloramphenicol, dari pus terhadap tetracycline, dari sputum terhadap erythromycin dan trimethoprimsulfamethoxazole $(p<0,05)$. Sementara itu didapatkan peningkatan resistensi terhadap chloramphenicol $(p<0,05)$ dari spesimen pus. Dapat disimpulkan bahwa prevalensi MRSA di RSUD dr. Saiful Anwar Malang, Indonesia cukup tinggi dan terjadi perubahan pola sensitifitas terhadap beberapa antibiotik.
\end{abstract}

Kata Kunci: Malang, MRSA, resistensi antibiotik, rumah sakit

\begin{abstract}
Methicillin Resistant Staphylococcus aureus (MRSA) is the most important pathogen causing the hospital-associated infections in the world. This study aimed to compare the prevalence and patterns of antibiotic resistance of MRSA isolates in Dr. Saiful Anwar Hospital in Malang, East Java, Indonesia during the period of 2010-2014. MRSA isolates were obtained from various clinical specimens, such as blood, pus, sputum, and urine. We detected MRSA isolates phenotypically, then performed antibiotic susceptibility according to the standard of Clinical and Laboratory Standards Institute (CLSI) 2014. Overall, 772 isolates of Staphylococcus aureus were obtained, 38,2\% of which was MRSA isolates. The highest prevalence of MRSA was obtained in 2012 (45,3\%), while the lowest prevalence was in 2013 (33,5\%). MRSA was most commonly found on pus (49\%). Decreasing resistance of MRSA isolates was found on blood against chloramphenicol, pus against tetracycline, sputum against erythromycin and trimethoprim-sulfamethoxazole $(p<0,05)$. However the increasing resistance against chloramphenicol was found on pus $(p<0,05)$. It can be concluded that MRSA prevalence in Dr. Saiful Anwar hospital Malang, Indonesia is quite high and there are pattern changes of sensitivity to some antibiotics.
\end{abstract}

Keywords: Antibiotic resistance, hospital, Malang, MRSA

Korespondensi: Dewi Erikawati. Laboratorium Mikrobiologi Fakultas Kedokteran Universitas Brawijaya Malang, Jl. Veteran Malang Jawa Timur Tel. (0341) 569117Email: erikawatidewi39@gmail.com 


\section{PENDAHULUAN}

Staphylococcus aureus (S. aureus) merupakan flora normal kulit namun dapat bersifat patogen pada host yang rentan. Bakteri ini mampu menyebabkan berbagai infeksi supuratif dengan angka keparahan yang bervariasi pada jaringan lunak, jaringan tulang, organ pernafasan, serta jaringan endovaskular yang menimbulkan manifestasi berbagai penyakit seperti furunkel, impetigo, osteomyelitis, tonsilitis, bronkhitis, pneumonia, endokarditis, meningoensefalitis, sampai sepsis (1-4).

Pada awal ditemukannya antibiotik penisilin pada tahun 1959, infeksi S. aureus dapat diatasi dengan mudah dengan pemberian antibiotik penisilin, namun dalam waktu dua tahun, muncul kasus pertama infeksi Staphylococcus aureus yang resisten terhadap methicillin, yang lebih dikenal dengan galur Methicillin Resistant Staphylococcus aureus (MRSA). Resistensi galur MRSA terhadap methicillin disebabkan oleh karena bakteri tersebut mendapatkan gen $\operatorname{mec} A$ yang mengkode protein penicillin-binding protein $2 a$ (PBP2a), yang memiliki afinitas yang rendah terhadap antibiotik golongan betalaktam seperti golongan penicillin, cephalosporine, dan carbapenem, serta kelompok antistaphylococcal penicillin, sementara bakteri tetap mampu mengkatalisis pembentukan dinding sel $(5,6)$.

Munculnya galur MRSA ini telah membuat pengobatan terhadap infeksi akibat Staphyloccus aureus semakin sulit. Terlebih lagi, saat ini, bakteri MRSA telah menyebar ke berbagai belahan dunia dan menjadi endemik di sebagian besar rumah sakit dan fasilitas kesehatan terutama pada negara-negara maju $(3,7)$. Banyaknya infeksi MRSA yang diiringi dengan peningkatan resistensi terhadap banyak golongan antibiotik (resistensi multidrug) menjadi perhatian utama di bidang infeksi. Di negara-negara berkembang, termasuk di Indonesia, belum banyak didapatkan data endemisitas bakteri MRSA, terutama prevalensi MRSA di rumah sakit (hospital-acquired MRSA/ HA-MRSA). Penelitian ini bertujuan untuk mengetahui tingkat prevalensi MRSA dari isolat klinik dan pola kepekaannya terhadap antibiotik di RSUD dr. Saiful Anwar Malang pada tahun 2010-2014.

\section{METODE}

\section{Sampel dan Metode Pengambilan Sampel}

Sampel yang diteliti merupakan spesimen klinik meliputi darah, pus, sputum, dan urin dari pasien yang dirawat selama kurun waktu tahun 2010-2014 di RSUD dr. Saiful Anwar Malang dan dikirimkan oleh dokter penanggung jawab pasien ke Instalasi Mikrobiologi Klinik RSUD dr. Saiful Anwar Malang. Masing-masing spesimen yang masuk akan menjalani proses kultur pada media pertumbuhan bakteri yang spesifik sesuai jenis spesimen dengan berpedoman pada standar prosedur operasional di Laboratorium Mikrobiologi RSUD Dr. Saiful Anwar Malang.

Metode pengambilan sampel dilakukan secara retrospektif crosssectional terhadap data hasil kultur sampel. Sampel yang diambil adalah semua spesimen darah, pus, sputum, dan urin yang menunjukkan pertumbuhan bakteri Staphylococcus aureus strain Methicillin Resistant Staphylococcus aureus (MRSA) sesuai standar dari Clinical and Laboratory Standards Institute (CLSI) 2014.

\section{Metode Kultur Isolat Bakteri}

Metode kultur spesimen darah dilakukan dengan cara berikut. Spesimen darah yang sudah diambil dari pasien dan ditempatkan di dalam botol kultur darah dimasukkan ke dalam inkubator khusus darah BACTEC ${ }^{\circledR}$ untuk diinkubasi sampai dideteksi adanya pertumbuhan mikroorganisme atau maksimal 5 hari. Apabila dideteksi adanya pertumbuhan mikroorganisme dalam botol darah yang ditandai (alarm detektor menyala), maka selanjutnya darah tersebut akan ditanam di media agar darah (Blood Agar). Media agar tersebut selanjutnya diinkubasi selama 18-24 jam dalam suhu $37^{\circ} \mathrm{C}$. Selanjutnya dilakukan pengamatan pertumbuhan koloni bakteri terpisah (murni) yang ada setelah masa inkubasi selesai, kemudian dilakukan pengecatan Gram dari koloni bakteri tersebut (8).

Pada spesimen pus, sputum dan urine dilakukan penilaian kualitas spesimen secara mikroskopis dengan pewarnaan Gram. Spesimen yang memenuhi syarat untuk dilanjutkan ke tahap kultur adalah bila ditemukan sel bakteri, sel PMN $>25 \mathrm{sel} / \mathrm{lpb}$, dan sel epitel skuamus (untuk spesimen pus dan sputum) $<10$ sel/lpb atau terlihat bakteri pada spesimen urin. Selanjutnya, spesimen yang memenuhi syarat kultur dinokulasikan pada medium perbenihan bakteri (medium agar) berdasarkan hasil pewarnaan Gram. Pada spesimen urin, spesimen yang diterima diambil beberapa tetes dengan ose steril, kemudian diletakkan di atas gelas objek dan pada spesimen urin tersebut, dilakukan pewarnaan Gram. Bila ditemukan bakteri Gram positif, maka kultur primer dilakukan pada medium Blood Agar, bila ditemukan bakteri Gram negatif, kultur primer dilakukan pada medium MacConkey Agar, bila ditemukan bakteri Gram positif dan Gram negatif, maka kultur primer dilakukan pada medium Blood Agar dan medium MacConkey Agar, kemudian semuanya diinkubasi pada suhu $37^{\circ} \mathrm{C}$ selama $18-24$ jam. Tahap terakhir dilakukan pengamatan diamati pertumbuhan koloni bakteri terpisah (murni) yang ada setelah masa inkubasi selesai, kemudian dilakukan pengecatan Gram dari koloni bakteri tersebut (8). Hasil pewarnaan Gram yang mendukung dugaan infeksi oleh bakteri MRSA adalah ditemukannya bentukan bakteri bulat (kokus) dan susunan bergerombol seperti buah anggur dan bersifat Gram positif.

\section{Metode Tes Katalase}

Tes katalase digunakan untuk membedakan genus Staphylococcus dengan Streptococcus. Kedua genus tersebut memiliki sifat pewarnaan Gram yang sama, yaitu Gram positif dan berbentuk kokus. Perbedaan kedua genus tersebut adalah keberadaan enzim sitokrom oksidase, yaitu genus Staphylococcus mempunyai enzim tersebut, sedangkan Streptococcus tidak. Prosedur pelaksanaan tes katalase pertama adalah membersihkan gelas objek yang akan digunakan dengan melewatkan gelas objek di atas nyala api sebanyak 3 kali. Selanjutnya dengan ose steril ambil 2-3 koloni kuman yang terpisah (murni) kemudian diletakkan di gelas objek. 1 tetes hidrogen peroksida $\left(\mathrm{H}_{2} \mathrm{O}_{2}\right) 30 \%$ diteteskan di atas koloni bakteri tersebut. Diamati terbentuknya gelembung udara, bila terbentuk gelembung udara dengan cepat dan banyak dinyatakan tes katalase positif. Sebaliknya, bila terbentuk gelembung sedikit dan terjadi setelah 20-30 detik tidak dapat dikatakan tes katalase positif. Bakteri kokus Gram positif yang menghasilkan tes katalase positif tersebut adalah golongan Staphylococcus sp. Apabila tes katalase negatif berarti bakteri yang tumbuh adalah golongan 
Streptococcus sp (9). Dari tes katalase ini, sampel yang diambil adalah isolat spesimen yang menghasikan tes katalase positif.

\section{Metode Tes Koagulase}

Tes koagulase adalah tes lanjutan yang dilakukan setelah mengidentifikasi bakteri Staphylococcus sp. setelah tes katalase. Tes koagulase ini bertujuan untuk mengidentifikasi bakteri Staphylococcus aureus, dimana hanya spesies bakteri tersebut yang menghasilkan tes koagulase positif di antara Genus bakteri Staphylococcus sp., dikarenakan mempunyai enzim koagulase. Prosedurnya diawali dengan mengambil satu lembar kertas karton hitam tahan air yang khusus digunakan untuk tes koagulase dari Remel ${ }^{\circledR}$. Kemudian meneteskan 1 tetes larutan Staphaurex ${ }^{\circledR}$ (Latex koagulase) di atas kertas karton tersebut. Selanjutnya satu koloni murni bakteri, yang telah teridentifikasi katalase positif dari medium perbenihan bakteri, diletakkan di atas larutan Staphaurex menggunakan lidi kayu. Kemudian kertas karton tersebut digoyang-goyangkan selama 30-60 detik. Jika timbul bentukan endapan seperti pasir-pasir kecil berwarna putih keabu-abuan, maka dinyatakan tes koagulase positif, yang menandakan bahwa isolat tersebut adalah spesies Staphylococcus aureus. Namun apabila tidak didapatkan bentukan butiran pasir, maka isolat bakteri tersebut adalah spesies Staphylococcus koagulase negative (10). Dari tes katalase ini, maka sampel yang diambil adalah isolat spesimen yang menghasikan tes koagulase positif.

\section{Metode Uji Kepekaan Antibiotik}

Pengujian kepekaan terhadap antibiotik dilakukan setelah proses identifikasi koloni bakteri Staphylococcus aureus selesai. Digunakan metode disc diffusion (Kirby Bauer method) dan pedoman menurut tabel yang dibuat oleh Clinical and Laboratory Standards Institute (CLSI) 2014. Pada metode ini digunakan kertas-kertas cakram berdiameter $6 \mathrm{~mm}$ yang telah berisi antibiotika dalam konsentrasi tertentu. Beberapa koloni bakteri Staphylococcus aureus yang terpisah dan murni diambil dengan ose steril kemudian dilarutkan dalam 2 ml larutan $\mathrm{NaCl}$ fisiologis sampai mencapai konsentrasi $0.5 \mathrm{Mc}$ Farland atau setara dengan kepadatan sel bakteri sebesar $1,5 \times 10^{8}$ bacteria/ml. Larutan $\mathrm{NaCl}$ fisiologis yang sudah berisi bakteri tersebut kemudian divortex agar homogen. Lidi kapas steril dimasukkan ke dalam tabung larutan $\mathrm{NaCl}$ tersebut untuk mengambil inokulum bakteri dan diinkubasi dalam suhu $37^{\circ} \mathrm{C}$ selama 30 menit. Selanjutnya, larutan $\mathrm{NaCl}$ fisiologis yang telah diinkubasi dikeluarkan dari inkubator, lidi kapas ditekan pelan ke permukaan bagian dalam dinding tabung yang berisi larutan $\mathrm{NaCl}$ tersebut, dipastikan tidak ada kelebihan cairan, kemudian lidi kapas ditarik keluar dari tabung. Lidi kapas digoreskan di atas Agar Mueller Hinton untuk membuat streaking pada permukaan Agar tersebut. Pembuatan streaking ini bertujuan untuk menumbuhkan koloni bakteri Staphylococcus aureus pada seluruh permukaan Agar. Agar Mueller Hinton dibiarkan mengering selama 2 menit, kemudian kertas cakram antibiotik cefoxitin, chloramphenicol, ciprofloxacin, erythromycin, gentamicin, tetracycline, dan trimethophrimsulfametoxazole diletakkan di atas Agar Mueller Hinton dengan jarak sebesar $24 \mathrm{~mm}$ dari bagian tengah kertas cakram satu antibiotik ke antibiotik lainnya. Agar Mueller Hinton diinkubasikan dalam inkubator pada suhu $37^{\circ} \mathrm{C}$ selama 24 jam setelah semua kertas cakram antibiotik terpasang (11).

Hambatan pertumbuhan bakteri di atas Agar Mueller Hinton selanjutnya diamati di sekitar cakram antibiotik cefoxitin, chloramphenicol, ciprofloxacin, erythromycin, gentamicin, tetracycline, dan trimethophrimsulfametoxazole setelah waktu inkubasi selesai. Selanjutnya dilakukan pengukuran diameter hambatan pertumbuhan bakteri untuk setiap jenis cakram antibiotika. Hasil pengukuran diameter hambatan pertumbuhan bakteri tersebut kemudian disesuaikan dengan tabel pengukuran kepekaan antibiotik yang dibuat oleh Clinical and Laboratory Standards Institute (CLSI) 2014, sehingga dapat ditentukan apakah bakteri yang diujikan masih sensitif atau sudah resisten terhadap suatu antibiotik. Bakteri Staphylococcus aureus strain MRSA teridentifikasi apabila didapatkan hasil resisten terhadap antibiotik cefoxitin (didapatkan hambatan pertumbuhan bakteri Staphylococcus aureus berdiameter $\leq 21 \mathrm{~mm}$ ) (11). Bakteri Staphylococcus aureus strain MRSA yang didapatkan diambil sebagai sampel penelitian.

Tabel 1. Nilai kepekaan bakteri Staphylococcus aureus terhadap cakram antibiotik berdasarkan pedoman Clinical and Laboratory Standards Institute (CLSI) 2014 (11)

\begin{tabular}{lccc}
\hline No Nama Antibiotik & \multicolumn{3}{c}{ Diameter Pengukuran } \\
\cline { 2 - 4 } & Sensitif & Intermediet & Resisten \\
\hline 1. Cefoxitin & $\geq 22 \mathrm{~mm}$ & - & $\leq 21 \mathrm{~mm}$ \\
2. Chloramphenicol & $\geq 18 \mathrm{~mm}$ & $13-17 \mathrm{~mm}$ & $\leq 12 \mathrm{~mm}$ \\
3. Ciprofloxacin & $\geq 21 \mathrm{~mm}$ & $16-20 \mathrm{~mm}$ & $\leq 15 \mathrm{~mm}$ \\
4. Erythromycin & $\geq 23 \mathrm{~mm}$ & $14-22 \mathrm{~mm}$ & $\leq 13 \mathrm{~mm}$ \\
5. Gentamicin & $\geq 15 \mathrm{~mm}$ & $13-14 \mathrm{~mm}$ & $\leq 12 \mathrm{~mm}$ \\
6. Tetracycline & $\geq 19 \mathrm{~mm}$ & $15-18 \mathrm{~mm}$ & $\leq 14 \mathrm{~mm}$ \\
7. Trimethoprim- & $\geq 16 \mathrm{~mm}$ & $11-15 \mathrm{~mm}$ & $\leq 10 \mathrm{~mm}$ \\
sulfamethoxazole & & & \\
\hline
\end{tabular}

\section{Analisis Hasil Penelitian}

Perbedaan profil kepekaan isolat MRSA terhadap antibiotik tersebut dari tahun 2010-2014 dianalisis dengan Chi-square (SPSS 16 for Windows). Nilai p adalah signifikan atau bermakna bila $\mathrm{p}<0,05$.

\section{HASIL}

Berdasarkan hasil analisis data kultur dan uji kepekaan antibiotik isolat MRSA dari spesimen klinik pasien rawat inap di RSUD dr. Saiful Anwar Malang pada tahun 20102014 didapatkan angka prevalensi seperti pada Tabel 2. Hasil menggambarkan jumlah total isolat S.aureus dan jumlah isolat MRSA dari masing-masing spesimen klinik, pada periode tahun 2010-2014. Isolat MRSA paling banyak didapatkan pada tahun 2012 (45,3\%) sedangkan prevalensi terendah pada tahun 2013 (33,5\%). Jenis spesimen yang paling banyak mengandung bakteri MRSA adalah pus (49\%).

Angka resistensi isolat MRSA dari masing-masing spesimen terhadap antibiotik yang diujikan tercantum pada Gambar $1-4$

Pada Gambar 1 terlihat adanya tingkat resistensi yang tinggi (>50\%) dari isolat MRSA yang ditemukan dari spesimen darah terhadap antibiotik ciprofloxacin, gentamicin, dan tetracycline. Data juga menunjukkan tren penurunan resistensi isolat MRSA terhadap antibiotik chloramphenicol $(p<0,05)$ dan trimethoprim 
Tabel 2. Prevalensi isolat MRSA dari spesimen klinik pasien rawat inap di RSUD dr. Saiful Anwar Malang pada tahun 2010-2014

\begin{tabular}{|c|c|c|c|c|c|c|c|c|c|c|}
\hline \multirow[t]{3}{*}{ Tahun } & \multicolumn{10}{|c|}{ Spesimen klinik } \\
\hline & \multicolumn{2}{|c|}{ Darah } & \multicolumn{2}{|c|}{ Pus } & \multicolumn{2}{|c|}{ Sputum } & \multicolumn{2}{|c|}{ Urin } & \multicolumn{2}{|c|}{ Total } \\
\hline & $\begin{array}{l}\text { Jumlah } \\
\text { isolat } S . \\
\text { aureus }\end{array}$ & $\begin{array}{c}\text { Jumlah } \\
\text { isolat } \\
\text { MRSA (\%)* }\end{array}$ & $\begin{array}{c}\text { Jumlah } \\
\text { isolat } S . \\
\text { aureus }\end{array}$ & $\begin{array}{c}\text { Jumlah } \\
\text { isolat } \\
\text { MRSA } \\
(\%)^{*}\end{array}$ & $\begin{array}{l}\text { Jumlah } \\
\text { isolat } S . \\
\text { aureus }\end{array}$ & $\begin{array}{c}\text { Jumlah } \\
\text { isolat } \\
\text { MRSA (\%)* }\end{array}$ & $\begin{array}{c}\text { Jumlah } \\
\text { isolat } S . \\
\text { aureus }\end{array}$ & $\begin{array}{c}\text { Jumlah } \\
\text { isolat } \\
\text { MRSA } \\
(\%)^{*}\end{array}$ & $\begin{array}{c}\text { Jumlah } \\
\text { isolat } S . \\
\text { aureus }\end{array}$ & $\begin{array}{c}\text { Jumlah } \\
\text { isolat MRSA } \\
(\%)^{*}\end{array}$ \\
\hline 2010 & 7 & $2(28,5)$ & 20 & $7(35)$ & 32 & $13(41)$ & 8 & $6(75)$ & 67 & $28(41,8)$ \\
\hline 2011 & 15 & $8(53)$ & 36 & $18(50)$ & 30 & $7(23)$ & 3 & $2(67)$ & 84 & $35(41,7)$ \\
\hline 2012 & 12 & $7(58)$ & 58 & $32(55)$ & 44 & $13(29,5)$ & 3 & $1(33)$ & 117 & $53(45,3)$ \\
\hline 2013 & 59 & 11(19) & 85 & $40(47)$ & 63 & $20(32)$ & 11 & $2(18)$ & 218 & $73(33,5)$ \\
\hline 2014 & 70 & $12(17)$ & 149 & $74(50)$ & 65 & 19(29) & 2 & $1(50)$ & 286 & $106(37,1)$ \\
\hline Total & 163 & $40(24,5)$ & 348 & $171(49)$ & 234 & $72(31)$ & 27 & $12(44)$ & 772 & $295(38,2)$ \\
\hline
\end{tabular}

Keterangan: *denominator=jumlah isolat $S$. aureus

\section{sulfamethoxazole.}

Pada Gambar 2, isolat MRSA dari spesimen pus menunjukkan tingkat resistensi yang tinggi (>50\%) terhadap antibiotik ciprofloxacin, gentamicin, dan tetracycline. Tingkat resistensi terhadap antibiotik chloramphenicol mengalami peningkatan, meskipun masih di bawah $50 \%(p<0,05)$. Selain itu tingkat resistensi isolat MRSA dari spesimen pus terhadap antibiotik trimethoprim-sulfamethoxazole juga mengalami peningkatan, meskipun tidak bermakna signifikan.

Gambar 3 menunjukkan tingkat resistensi yang tinggi (>50\%) dari isolat MRSA diamati pada antibiotik erythromycin, ciprofloxacin, gentamicin, dan tetracycline. Pada antibiotik trimethoprim-sulfamethoxazole terjadi penurunan level resistensi yang bermakna $(p<0,05)$. Tidak terjadi perubahan level resistensi yang bermakna pada antibiotik chloramphenicol.

Pada Gambar 4 terlihat adanya tingkat resistensi yang tinggi (>50\%) dari isolat MRSA pada antibiotik chloramphenicol, ciprofloxacin, gentamicin, dan tetracycline. Antibiotik trimethoprim-sulfamethoxazole sangat sensitif terhadap isolat MRSA yang ditemukan dari spesimen urin.

\section{DISKUSI}

Prevalensi isolat MRSA di RSUD dr. Saiful Anwar Malang cukup bervariasi dari tahun 2010 sampai 2014. Pada tahun 2010, prevalensi mencapai 41,8\% dan pada tahun 2011 tidak jauh berbeda dengan tahun 2010, yaitu $41,7 \%$. Sebagai data awal, prevalensi tersebut cukup tinggi bila dibandingkan dengan prevalensi dari negara lain seperti di Finlandia, Denmark, Norwegia, Iceland, Swedia, dan Belanda, yang telah menerapkan prinsip "search and destroy" dalam upaya menurunkan prevalensi hospital acquired MRSA (HA-MRSA) (5). Dibandingkan dengan prevalensi MRSA di negara Asia seperti Hongkong di tahun 2010 yaitu sebesar 25\%, prevalensi di RSUD dr. Saiful Anwar Malang juga lebih tinggi (12).

Prevalensi infeksi HA-MRSA bervariasi antar daerah/negara, bergantung dari upaya menurunkan kolonisasi dan penyebaran bakteri ini di rumah sakit yang dimaksud. Meskipun di negara-negara Eropa tersebut angka infeksi MRSA tergolong cukup rendah, sebuah survei yang diadakan oleh negara-negara Eropa yaitu EARSS (European Antimicrobial Resistance Surveillans System) pada tahun 2011 menyebutkan bahwa bakteri MRSA masih menyebabkan lebih dari $25 \%$ kejadian infeksi di

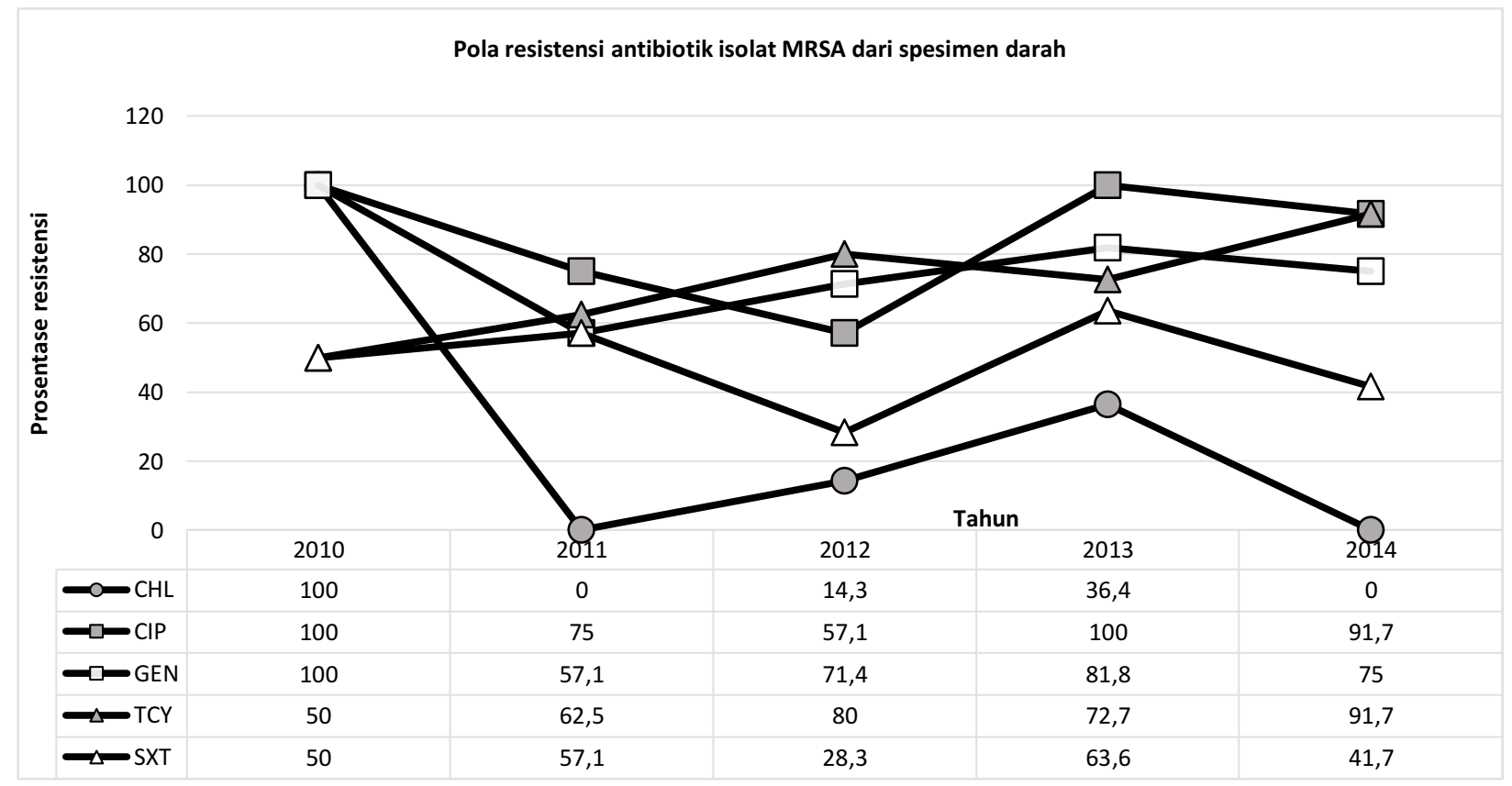

Gambar 1. Pola resistensi antibiotik isolat MRSA dari spesimen darah di RSUD dr. Saiful Anwar Malang tahun 2010-2014 Keterangan: CHL: chloramphenicol, CIP: ciprofloxacin, GEN: gentamicin, TCY: tetracycline, SXT: trimethoprim-sulfamethoxazole 
Pola resistensi antibiotik isolat MRSA dari spesimen pus

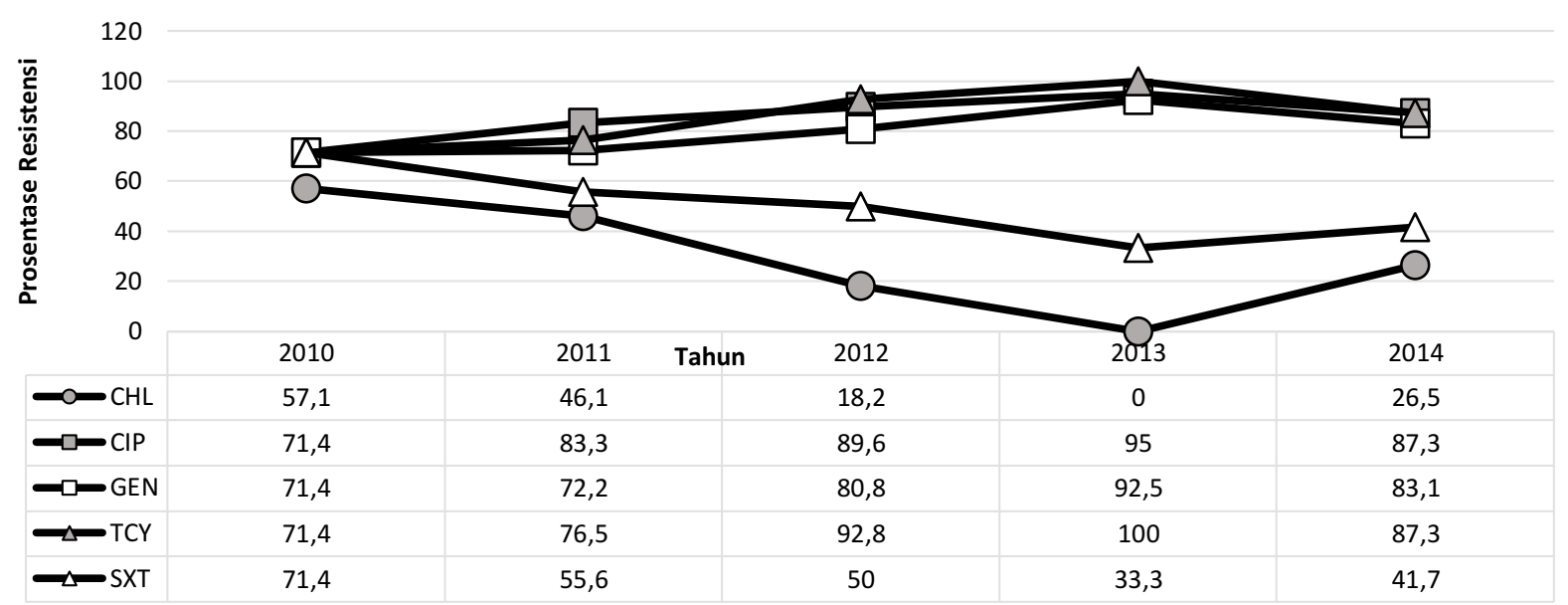

Gambar 2. Pola resistensi antibiotik isolat MRSA dari spesimen pus di RSUD dr. Saiful Anwar Malang tahun 2010-2014 Keterangan: CHL: chloramphenicol, CIP: ciprofloxacin, GEN: gentamicin, TCY: tetracycline, SXT: trimethoprim-sulfamethoxazole

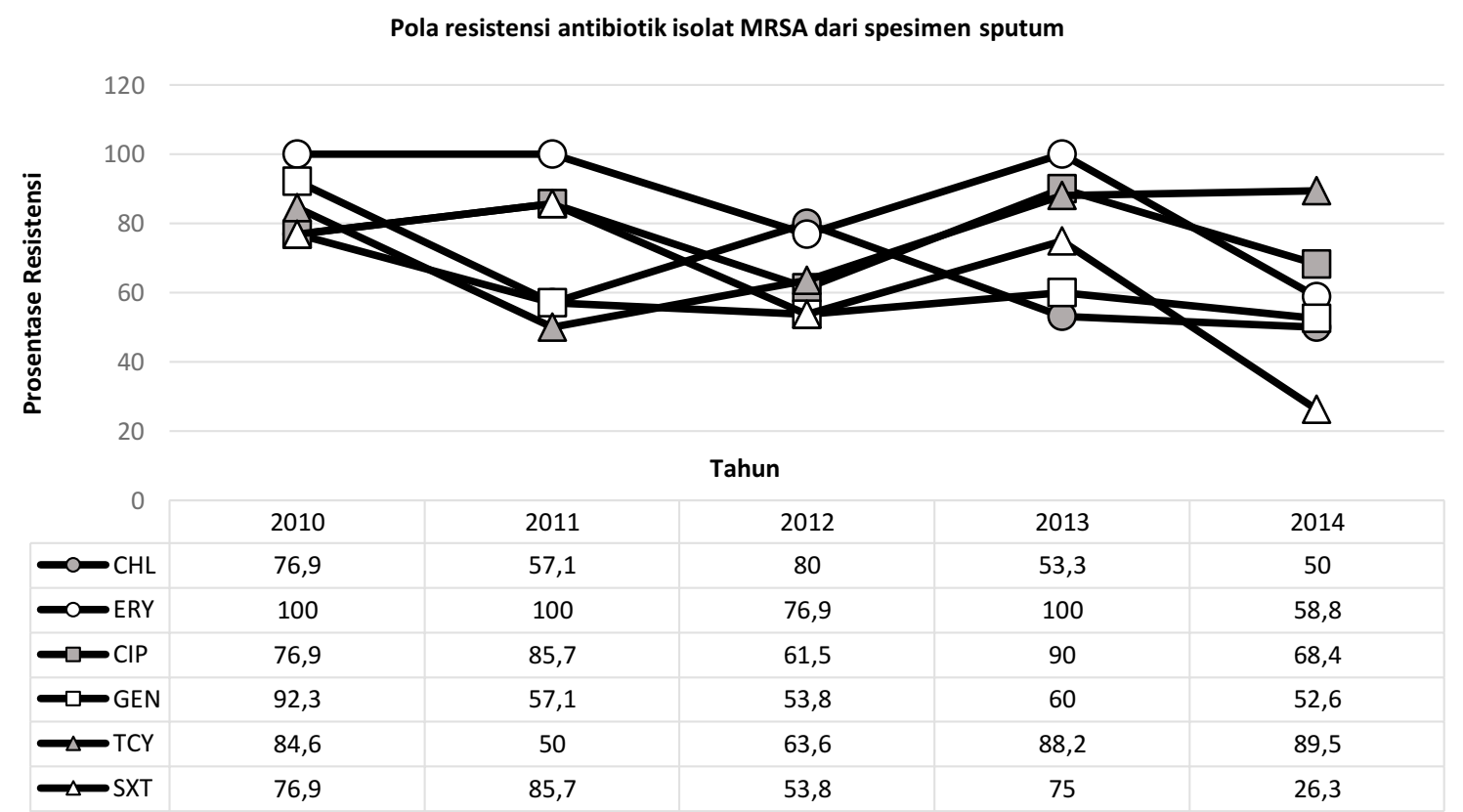

Gambar 3. Pola resistensi antibiotik isolat MRSA dari spesimen sputum di RSUD dr. Saiful Anwar Malang tahun 2010-2014

Keterangan: CHL: chloramphenicol, ERY: erythromycin, CIP: ciprofloxacin, GEN: gentamicin, TCY: tetracycline, SXT: trimethoprim-sulfamethoxazole

aliran darah di sepertiga negara-negara Eropa yang terlibat dalam studi (5).

Dari keempat spesimen yang paling banyak dikirimkan ke Instalasi Mikrobiologi RSUD dr. Saiful Anwar Malang, MRSA paling banyak ditemukan dari spesimen pus (49\%). Hal ini merupakan hal yang wajar, mengingat bakteri S.aureus merupakan flora normal kulit manusia yang sering melakukan invasi, menginfeksi luka, dan menyebabkan peradangan supuratif saat barrier pertahanan kulit mengalami kerusakan, dengan ciri khasnya memproduksi pus (2).

Prevalensi MRSA terutama MRSA yang beredar di rumah sakit atau hospital acquired MRSA (HA-MRSA) mencerminkan tingkat infeksi nosokomial di suatu rumah sakit. Apabila prevalensi MRSA tinggi, maka dapat megindikasikan bahwa tingkat infeksi nosokomial di rumah sakit tersebut juga tinggi. Pada tahun 2012, terjadi peningkatan prevalensi MRSA yaitu mencapai angka 45,3\%. Hal ini mengindikasikan bahwa semakin meningkatnya angka kejadian infeksi MRSA di RSUD dr. Saiful Anwar. Hal tersebut dapat disebabkan penggunaan antibiotik yang tidak tepat indikasi, dosis, dan durasi pemakaian, maupun semakin meningkatnya kejadian infeksi nosokomial. Sebelum tahun 2012, belum dilakukan surveilans aktif mengenai prevalensi MRSA di RSUD dr. Saiful Anwar Malang, sehingga kesadaran tentang ancaman infeksi nosokomial terutama MRSA masih rendah, yang akhirnya menyebabkan kurangnya tindakan pengendalian resistensi antibiotik maupun infeksi nosokomial.

Pada tahun 2012, diadakan program skrining terhadap MRSA di RSUD dr.Saiful Anwar yang disertai dengan tindakan intervensi berupa edukasi cuci tangan pada 


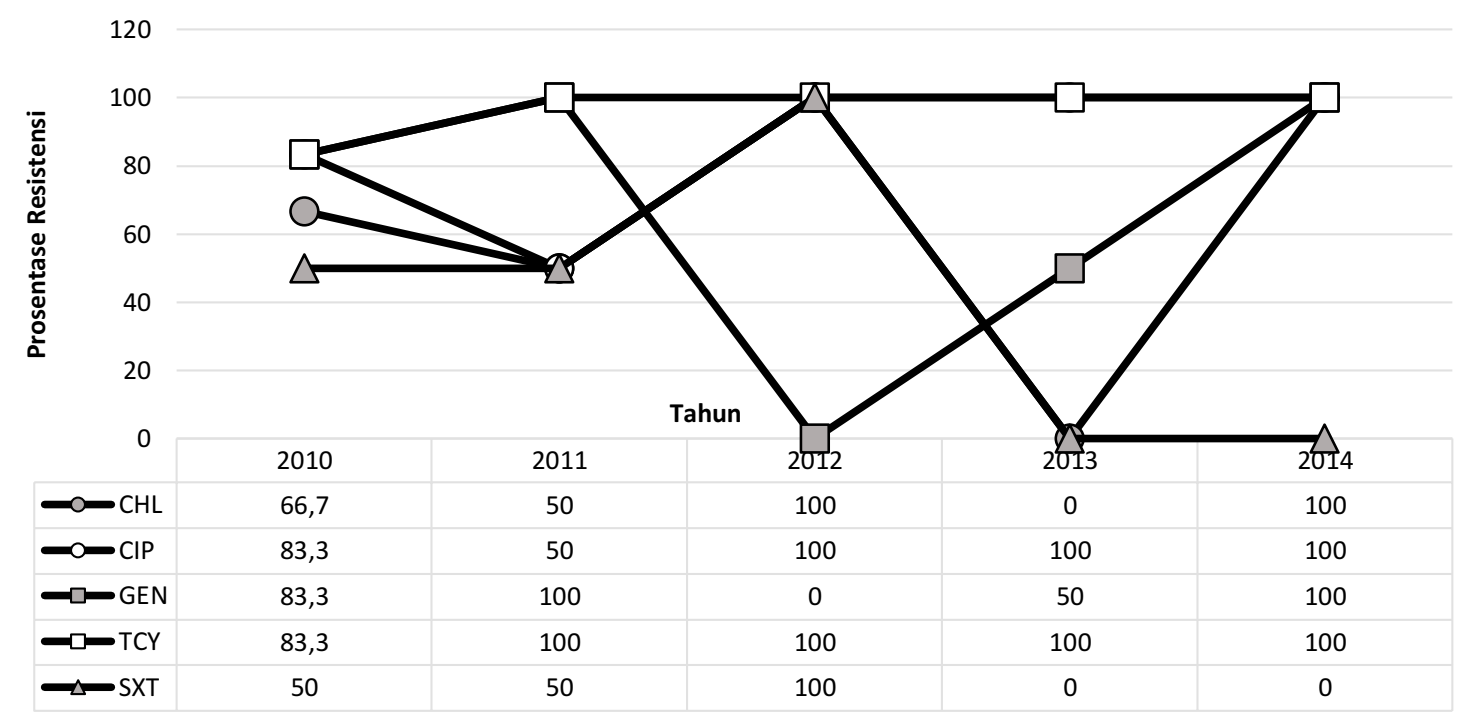

Gambar 4. Pola resistensi antibiotik isolat MRSA dari spesimen urin di RSUD dr. Saiful Anwar Malang tahun 20102014 Keterangan: CHL: chloramphenicol, CIP: ciprofloxacin, GEN: gentamicin, TCY: tetracycline, SXT: trimethoprim-sulfamethoxazole

petugas kesehatan, dekontaminasi bangsal perawatan, dan tindakan dekolonisasi bakteri MRSA pada pasien yang dirawat serta petugas kesehatan yang berstatus carrier MRSA di rongga hidung dan tenggoroknya. Dampak dari program skrining dan tindakan intervensi pada tahun 2012 tersebut cukup memuaskan dengan didapatkannya penurunan angka prevalensi MRSA pada tahun 2013, yaitu menurun sampai sebesar $33,5 \%$.

Penurunan angka karier MRSA yang diikuti dengan penurunan angka prevalensi MRSA pada tahun 2013 tersebut sejalan dengan studi oleh Cookson et al, dan Buehlmann et al. Kedua studi tersebut menyebutkan bahwa pada suatu daerah dengan endemisitas MRSA cukup tinggi, tindakan skrining yang dilanjutkan dengan dekolonisasi bakteri MRSA pada pasien yang dirawat dan petugas kesehatan yang bertindak sebagai karier bakteri, merupakan pilar utama dalam program mengendalikan endemisitas bakteri MRSA $(13,14)$. Skrining dan dekolonisasi di lingkungan perawatan turut membantu keberhasilan program tersebut. Selain itu, manfaat yang dapat dirasakan karena tindakan eradikasi MRSA tersebut adalah penghematan biaya perawatan pasien selama dirawat di rumah sakit.

Didapatkan angka peningkatan prevalensi MRSA menjadi $37 \%$ pada tahun 2014. Peningkatan prevalensi ini menjadi peringatan bagi para petugas kesehatan dan pemegang kebijakan rumah sakit, apakah tindakan pencegahan resistensi antibiotik dan pengendalian infeksi nosokomial di rumah sakit sudah cukup efektif, dijalankan di semua unit perawatan pasien, dan dijalankan secara berkesinambungan. Beberapa faktor yang dapat mempengaruhi terjadinya infeksi MRSA di lingkungan rumah sakit/HA-MRSA antara lain perawatan yang lama di rumah sakit atau pusat perawatan jangka panjang (panti jompo, pusat rehabilitasi), riwayat pembedahan, pemasangan alat invasif ke dalam tubuh seperti kateter infus, tindakan dialysis, riwayat penggunaan antibiotik, dan keadaan immunocompromised $(4,15)$.

Menurut Centers for Diseases Control and Prevention
(CDC), ada lima keadaan yang dapat meningkatkan risiko transmisi bakteri MRSA. Lima keadaan tersebut antara lain kepadatan populasi manusia, kontak kulit-ke-kulit yang intens/sering, integritas kulit yang terganggu, adanya permukaan benda atau lingkungan yang terkontaminasi bakteri MRSA, dan kurangnya kebersihan (3). Hal-hal tersebut di atas merupakan informasi penting yang harus diperhatikan dalam perumusan kebijakan pencegahan dan pengendalian infeksi nosokomial terkait infeksi HA-MRSA.

Hasil uji kepekaan antibiotik menunjukkan tingkat resistensi dari isolat MRSA terhadap antibiotik pada masing-masing spesimen dari tahun 2010-2014 yang bervariasi. Didapatkan perbedaan yang bermakna pada angka resistensi antibiotik chloramphenicol pada spesimen darah, chloramphenicol dan tetracycline pada spesimen pus, serta erythromycin dan trimethoprimsulfamethoxazole pada spesimen sputum. Tingkat resistensi antibiotik chloramphenicol pada spesimen darah menunjukkan adanya kecenderungan penurunan resistensi (sebesar 34,6\% dari tahun 2013 ke tahun 2014), sedangkan angka resistensi antibiotik chloramphenicol pada spesimen pus menunjukkan tren peningkatan (sebesar 26,5\% dari tahun 2013 ke tahun 2014), meskipun besarnya angka resistensi masih dibawah $50 \%$. Tingkat resistensi antibiotik tetracycline pada spesimen pus, antibiotik erythromycin dan trimethoprimsulfamethoxazole pada spesimen sputum, menunjukkan tren penurunan angka resistensi (masing-masing sebesar 12,7\%, 41,2\%, dan 48,7\% dari tahun 2013 ke tahun 2014). Hal tersebut mengindikasikan bahwa ada perbedaan dalam pola penggunaan antibiotik tersebut dari tahun ke tahun di RSUD dr. Saiful Anwar Malang, yang akhirnya mempengaruhi angka resistensi isolat MRSA terhadap antibiotik. Adanya kecenderungan peningkatan angka resistensi sebaiknya dihindari atau dikendalikan pada masa kini dan mendatang agar tidak berkembang lebih jauh lagi, oleh karena itu harus segera diinformasikan kepada para klinisi di rumah sakit.

Pada setiap tabel tingkat resistensi, didapatkan sebagian 
kecil isolat MRSA memiliki angka resistensi di bawah 50\%, sedangkan sebagian besar di atas 50\%. Hal ini mengindikasikan bahwa isolat MRSA yang beredar di lingkungan RSUD dr. Saiful Anwar adalah isolat yang bersifat multidrug resistant MRSA, yang merupakan ciri khas isolat hospital acquired MRSA (HA-MRSA) $(3,16)$. Hasil tersebut juga mengindikasikan bahwa pasien yang menjalani rawat inap di RSUD dr. Saiful Anwar kemungkinan mendapatkan infeksi MRSA selama dirawat di rumah sakit atau lebih sering disebut dengan infeksi nosokomial. Tingginya angka infeksi nosokomial di suatu rumah sakit bukanlah suatu hal yang baik, karena mencerminkan adanya transmisi silang atau transmisi mikroba patogen pada pasien yang sebelumnya dirawat bukan karena penyakit infeksi, tingginya angka infeksi nosokomial juga dapat memperparah keadaan sakit pasien yang menjalani rawat inap, memperpanjang lama perawatan, dan menimbulkan risiko yang tinggi bagi para petugas kesehatan untuk terinfeksi mikroba patogen dari lingkungan atau pasien di rumah sakit.

Pada spesimen darah, didapatkan angka resistensi yang tinggi pada antibotika ciprofloxacin, gentamicin, tetracycline, dan trimethoprim-sulfamethoxazole. Angka resistensi antibiotik spesimen pus yang tinggi juga didapatkan pada antibiotik ciprofloxacin, gentamicin, dan tetracycline. Sementara itu, pada spesimen sputum, didapatkan angka resistensi antibiotik yang tinggi pada ciprofloxacin, erythromycin, gentamicin, tetracycline. Demikian pula pada spesimen urin, resistensi antibiotik yang tinggi terjadi pada hampir semua antibiotik yang diujikan, kecuali trimethoprim-sulfamethoxazole. Hal tersebut menandakan bahwa pemakaian antibiotikantibiotik tersebut cukup sering pada pasien yang dirawat di RSUD dr. Saiful Anwar Malang, sehingga memicu terjadinya resistensi. Penggunaan antibiotik tersebut tidak hanya di lingkungan rumah sakit, namun juga di komunitas (masyarakat), mengingat masih tingginya konsumsi antibiotik tanpa resep dokter di masyakat. Masyarakat cenderung membeli sendiri, dengan pola konsumsi yang tidak sesuai dosis maupun aturan pemakaian (17). Penggunaan antibiotik secara bebas seharusnya diatur untuk mengendalikan angka resistensi, dengan pembuatan regulasi yang ketat dalam peresepan dan pembelian antibiotik, baik di lingkungan rumah sakit maupun di komunitas.

Salah satu hasil yang menarik dari penelitian ini adalah bahwa antibiotik trimethoprim-sulfamethoxazole memiliki angka resistensi yang cenderung menurun pada isolat MRSA yang didapatkan dari darah, sputum, dan urin (pada darah sebesar $21,9 \%$, pada sputum sebesar $48,7 \%$, dari tahun 2013 ke tahun 2014, dan pada urin sebesar 100\% dari tahun 2012 ke tahun 2013 dan 2014). Pada spesimen pus, meskipun terjadi peningkatan angka resistensi dari tahun 2013 ke tahun 2014 sebesar 8,4\%,

\section{DAFTAR PUSTAKA}

1. Gordon RJ and Lowy FD. Pathogenesis of MethicillinResistant Staphylococcus aureus Infection. Clinical Infectious Disease. 2008; 46(5): S350-S359.

2. Brooks GF, Caroll KC, and Butel JS, Morse SA, and Mietzer TA. Jawetz, Melnick \& Adelberg's Medical Microbiology International Edition. Edisi 25. New York: McGraw-Hill Companies; 2010: hal. 185-190. tingkat besaran resistensi masih di bawah 50\%. Antibiotik dengan besaran angka resistensi kurang dari 50\% masih layak untuk diberikan sebagai terapi antimikroba. Dari kedua analisis tersebut, dapat disimpulkan bahwa antibiotik trimethoprim-sulfamethoxazole masih memiliki kepekaan/sensitifitas yang baik dalam melawan bakteri MRSA yang didapatkan pada sebagian besar spesimen klinik.

Dari penelitian ini, dapat direkomendasikan beberapa antibiotik pilihan untuk terapi bakteri MRSA yg didapatkan dari masing-masing spesimen. Antibiotik chloramphenicol dapat digunakan untuk terapi bakteri MRSA yg berasal dari spesimen pus. Sementara itu, antibiotik trimethoprimsulfamethoxazole dapat digunakan sebagai antibiotik pilihan untuk terapi bakteri MRSA yang didapatkan dari pus, sputum, dan urin. Antibiotik chloramphenicol dan trimethoprim-sulfamethoxazole tidak lagi direkomendasikan untuk terapi bakteri MRSA yang didapatkan dari spesimen darah. Dalam hal pengendalian infeksi MRSA, sebaiknya program eradikasi atau dekolonisasi dan pencegahan transmisi MRSA baik antar pasien maupun antara pasien dengan petugas kesehatan serta lingkungan dijalankan dengan baik, berkesinambungan, yang diikuti dengan kegiatan surveillans untuk memonitor keberhasilan programprogram tersebut.

Pada penelitian ini belum dilakukan penyelidikan status klinis dari masing-masing pasien yang terinfeksi oleh MRSA pada periode tahun 2010-2014 karena data klinis yang belum terintegasi. Status klinis seperti diagnosis klinis pasien, tipe infeksi yang dialami, riwayat dirawat di rumah sakit lain sebelumnya, riwayat pembedahan, riwayat pemasangan alat-alat invasif, dan riwayat terapi antibiotik, akan sangat membantu dalam menggambarkan kondisi infeksi MRSA di RSUD dr. Saiful Anwar Malang. Integrasi data klinis dan laboratoris menjadi penting untuk investigasi pola dan penyebab MRSA di rumah sakit sebagai dasar dalam menyusun kebijakan penggunaan antibiotik.

Penelitian ini membuktikan adanya prevalensi MRSA yang tinggi dari spesimen klinik pasien yang dirawat di RSUD dr. Saiful Anwar, Malang, Indonesia pada tahun 2010-2014, disertai perubahan pola resistensi terhadap berbagai kelas antibiotik yang sering digunakan. Hasil penelitian dapat dijadikan dasar dalam kebijakan penggunaan antibiotik secara rasional.

\section{UCAPAN TERIMA KASIH}

Kami mengucapkan terima kasih kepada Direktur RS Umum Daerah dr. Saiful Anwar Malang yang telah memfasilitasi penelitian ini dan seluruh staf, analis serta administrasi Instalasi Mikrobiologi Klinik RS Umum Daerah dr. Saiful Anwar Malang yang telah membantu dalam pengerjaan kultur dan peta kuman.
3. DeLeo FR, Otto M, Kreiswirth BN, and Chambers HF. Community-Associated Methicillin Resistant Staphylococcus aureus. Lancet. 2010; 375(9725): 1557-1568.

4. Ray P, Gautam V, and Singh R. Methicillin-Resistant Staphylococcus aureus (MRSA) in Developing and Developed Countries: Implications and Solutions. Proceeding Regional Health Forum. 2011; 15(1): 7482. 
5. Moellering Jr RC. MRSA: The First Half Century. Journal of Antimicrobial Chemotherapy. 2012; 67(1): 4-11.

6. Fey PD, Said-Salim B, Rupp ME, et al. Comparative Molecular Analysis of Community- or HospitalAcquired Methicillin-Resistant Staphylococcus aureus. Antimicrobial Agents Chemotherapy. 2003; 47(1): 196-203.

7. Mejfa C, Zurita J, and Guzman-Blanco M. Epidemiology and Surveillance of MethicillinResistant Staphylococcus aureus in Latin America. The Brazilian Journal Infectious Disease. 2010; 14(2): S79-S86.

8. Santoso S, Santosaningsih D, Erikawati D, et al. Panduan Praktik Klinis Prosedur Tindakan. Edisi 1. Malang: Instalasi Mikrobiologi Klinik RSUD Dr. Saiful Anwar; 2013; hal. 2-50.

9. Forbes BA, Sahm DF, and Weissfeld AS. Overview of Bacterial Identification Method and Strategies. In: Forbes BA, Sahm DF, and Weissfeld AS (Eds). Bailey \& Scott's Diagnostic Microbiology 12th edition. St. Louis Missouri: Mosby Elsevier; 2007: p. 221.

10. Forbes BA, Sahm DF, Weissfeld AS. Laboratory Method and Strategies for Antimicrobial Susceptibility Testing. In: Forbes BA, Sahm DF, and Weissfeld AS (Eds). Bailey \& Scott's Diagnostic Microbiology 12th edition. St. Louis Missouri: Mosby Elsevier; 2007: pp. 194-198.

11. Patel JB, Cockerill III FR, Alder J, et al. Zone Diameter and Minimum Inhibitory Concentration (MIC) Interpretive Standards for Staphylococcus spp. In:
Performance Standards for Antimicrobial Susceptibility Testing Twenty Fourth Informational Supplement Vol 34 No 1. Pennsylvania: Clinical and Laboratory Standards Institute; 2014: p. 68-75.

12. Chen CJ and Huang YC. New Epidemiology of Staphylococcus aureus in Asia. Clinical Microbiology and Infection. 2014; 20(7): 605-623.

13. Cookson B, Bonten MJ, MacKenzie FM, et al. Methicillin-Resistant Staphylococcus aureus (MRSA): Screening and Decolonization. International Journal of Antimicrobial Agents. 2011; 37(3): 195-201.

14. BuehImann M, Frei R, Fenner L, Dangel M, Fluckiger $U$, and Widmer AF. Highly Effective Regimen for Decolonization of Methicillin-Resistant Staphylococcus aureus Carriers. Infectious Control Hospital Epidemiology. 2008; 29(6): 510-516.

15. Graffunder EM and Venezia RA. Risk Factors Associated with Nosocomial Methicillin-Resistant Staphylococcus aureus (MRSA) Infection including Previous Use of Antimicrobials. Journal of Antimicrobial Chemotherapy. 2002; 49(6): 999-1005.

16. Evan RP. The Silent Epidemic: CA-MRSA and HA-MRSA, Recommendations for Prevention, Identification, and Treatment. (O n I i n e ) 2008 . http://www.aaos.org/news/aaosnow/may08/resear ch1.asp [diakses 10 Januari 2015].

17. Hadi U, Doerink DO, Lestari ES, et al. Survey of Antibiotic Use of Individual Visiting Public Healthcare Facilities in Indonesia. International Journal of Infectious Diseases. 2008; 12(6): 622-629. 